\title{
Optical Imaging and Its Clinical Application in Otorhinolaryngology
}

\author{
Sang Joon Lee \\ Department of Otorhinolaryngology-Head and Neck Surgery, Dankook University College of Medicine, Cheonan, Korea
}

\section{광영상의 이비인후과 영역에서 임상적 적용}

\author{
이 상 준 \\ 단국대학교 의과대학 이비인후-두경부외과학교실
}

Received February 17, 2015

Accepted March 16, 2015

Address for correspondence

Sang Joon Lee, MD, PhD

Department of Otorhinolaryngology-

Head and Neck Surgery,

Dankook University

College of Medicine,

119 Dandae-ro, Dongnam-gu,

Cheonan 330-714, Korea

Tel $+82-41-550-3975$

Fax +82-41-556-1090

E-mail 1sj72@dankook.ac.kr
Optical imaging visualizes tissue function and structure by analyzing the properties of absorption, scattering, or reflection. Light in the near-infrared spectrum relatively penetrate human tissue well. Diffuse optical imaging (DOI) is a functional imaging modality which can evaluate the perfusion and metabolism of human tissue and tumor by analyzing the optical properties of hemoglobin, water, and lipid. Optical coherence tomography (OCT) acquires the cross-sectional images by analyzing the coherence pattern of the reflected light from the human tissue. OCT has higher resolution more than 15 times compared to conventional imaging modalities like ultrasonography, computed tomography, or magnetic resonance imaging. Optical imaging has advantages of harmlessness, noninvasiveness, and high resolution. However, it has limitation in the penetration depth. In this review, mechanism of DOI and OCT and their clinical application in the otorhinolaryngology field will be discussed.

Korean J Otorhinolaryngol-Head Neck Surg 2015;58(4):229-35

Key Words Diffuse optical imaging · Near-infrared · Optical coherence tomography.

\section{서 론}

빛이 물질에 조사되면 일부가 흡수되거나, 반사되거나 혹은 산란된다. 만일 균일한 농도의 물질이면 투과 전후의 빛의 세기를 측정함으로써 물질의 농도를 알아낼 수 있다. 인체조 직은 혈색소(hemoglobin), 물, 지방 등 여러 성분으로 이루어 져 있으므로 여러 파장의 빛을 사용하여 각각의 흡수되는 정 도를 측정하여 각 물질의 농도를 계산할 수 있다. 이때 주로 650 1400 nm의 근적외선(near-infrared light)이 사용되는 데, 이 영역의 파장이 비교적 사람의 조직에 투과가 잘 되기 때 문이다. ${ }^{1)}$ 또한 혈색소의 흡수 스펙트럼은 산화(oxygenation) 의 정도에 따라 달라지는 특성이 있어 조직의 관류(perfusion) 나 산소포화도를 측정할 수 있다. ${ }^{2)}$

이러한 원리를 이용하여 조직의 기능적 영상을 얻는 것을 기 능적 근적외선분광영상(functional near-infrared spectros- copy, fNIRS)이라고 한다. 확산광분광영상(diffuse optical spectroscopic imaging, DOSI)은 큰 의미에서 근적외선분광영상 에 포함되는 것으로 조직내의 빛의 흡수계수와 산란 계수의 분포를 재구성하여 영상을 만들어 내는 것이다. 이에 반해 광 간섭단층촬영(optical coherence tomography, OCT)은 조직 내 여러 층에서 반사된 빛을 모아 서로 간섭시켜 조직의 해부 학적 영상을 얻는 방법이다.

근적외선을 이용한 광영상기술은 인체에 무해하고 비침습 적이어서 생체조직에 바로 적용이 가능한 장점이 있으며, 기술 발달에 따라 점차 소형화되어 실시간 분석이 가능해지고 있 다. 본 논문에서는 확산광분광영상과 광간섭단층촬영에 대 해 소개하고 이비인후과 영역에서 임상적 적용가능성에 대해 알아보고자 하였다. 


\section{확산광분광영상(Diffuse Optical Spectroscopic Imaging, DOSI)}

확산광영상(diffuse optical imaging, DOI)은 600 1000 nm 의 적색 및 근적외선의 빛을 이용하여 생체내의 광학적 특성 을 센티미터 두께 정도까지 분석할 수 있다. 조직 내에 존재하는 혈색소, 물, 지방, 포피린(porphyrins), 시토크롬(cytochromes) 과 같은 분자가 적색 및 근적외선 영역의 빛을 흡수하여 영상 의 대비(contrast)를 만들게 된다. 확산광영상은 주로 기능적 영상이며 조직의 관류나 대사 과정과 같은 생리학적 영상을 얻 을 수 있다. ${ }^{3)}$

연속파(continuous wave, $\mathrm{CW}$ ) 방식이 가장 빠르고 경제적 이며, 혈색소 등 조직내 발색소(chromophore) 농도의 변화를 쉽게 측정할 수 있다. 이처럼 여러 파장대의 연속파를 사용하 여 측정하는 방식을 일반적으로 근적외선분광영상(near-infrared spectroscopy, NIRS)이라고 부른다. .) 연속파 근적외 선분광영상(CW-NIRS)은 일반적으로 조직내의 산란을 고려 하지 않으므로 절대치를 알 수 없으며, 주로 뇌나 근육에서 혈 행학적 변화를 측정하기 위해서 사용된다. ${ }^{4}$

시간영역(time domain) 방식은 $10^{-12}$ 초 정도의 간헐적인 빛 (pulsed light)을 이용하여 조직 통과 후 빛의 감쇄(attenuation) 및 광역화(broadening)의 정도를 측정함으로써 조직의 흡수 및 산란특성을 알아낸다. ${ }^{5)}$ 주파수영역(frequency domain) 방 식 또한 조직의 흡수 및 산란 특성을 구별하여 측정할 수 있다. 그러나 간헐파를 사용하는 대신 세기 변조된 빛(intensity modulated light)을 사용한다. 세기 변조된 빛이 조직을 통과하면 서 산란에 의해 속도가 감소되게 되는데 이는 입력신호와 출력 신호 사이의 위상변화(phase shift)로 나타나며, 출력신호의 진 폭의 감쇄(ampltitude attenuation)는 흡수 특성을 반영한다 (Fig. 1). ${ }^{3)}$ 광학적 성질을 주파수 영역 방식으로 측정하는 것은 시간영역 방식의 확장이며 1980년 후반부터 연구되어 왔다. ${ }^{6.7)}$ 1990년대에 이르러 조직모형이나 생체조직에서 주파수 영역 방식으로 광학적 성질을 측정하였으며, 이후 측정기기의 소형
화가 진행되어 뇌, 근육, 유방 등 여러 조직에서 적용되었다. ${ }^{3,4}$

확산광분광영상(DOSI)은 Bevilacqua 등이이 연속파 근적 외선분광영상과 주파수영역 방식의 원리를 결합하여 개발한 광학측정 시스템으로 확산광영상의 일종이다. 확산광분광영 상은 두꺼운 조직에서 빛의 흡수와 산란을 측정하기 위하여 파장이 650 1000 nm인 6개의 다이오드 레이저 및 광대역 램 프(broadband lamp)를 광원으로 이용한다. 진폭의 변화 및 위상지연을 분석함으로써 각 레이저 파장별로 흡수계수 및 산란계수를 구할 수 있으며 측정된 흡수 스펙트럼을 기존의 흡수 스펙트럼에 맞추어 봄으로써 산화혈색소(oxygenated hemoglobin), 탈산화혈색소(deoxygenated hemoglobin), 물, 지방의 조직 내 절대 농도를 구할 수 있다.9)

손에 쥘 수 있는 탐침(probe)을 이용하여 측정을 하는데, 탐 침은 크게 레이저 다이오드와 광대역 램프에서 나오는 광원 을 조직에 조사하는 광원부(source), 조직에서 투과되어 나온 빛을 측정하는 검출부(detector)로 구성된다. 검출부는 레이 저를 검출하여 전기적 신호로 바꾸는 설붕광다이오드(avalanche photodiode, APD) 검출기와 광대역 광원을 스펙트 럼 분석기(spectrometer)로 보내는 광섬유로 구성된다. 조직을 분석하는 깊이는 일반적으로 광원부와 검출부 거리의 $1 / 2$ 이 다. 예를 들어 둘 사이가 $3 \mathrm{~cm}$ 떨어져 있는 경우 $1.5 \mathrm{~cm}$ 깊이의 조직이 측정된다. 현재의 모델은 초기 모델의 여러 구성요소를 인쇄회로기판에 소형화함으로써 이동성이 훨씬 향상되었으며 측정시간 및 비용 또한 5 배 이상 개선되었다(Fig. 2A). ${ }^{10)}$

\section{근적외선분광영상 및 확산광분광영상의 임상적 적용}

확산광분광영상의 장점은 비침습적으로 조직의 대사 및 혈류 정보를 알아낼 수 있는 점이다. 산화혈색소, 탈산화혈색 소, 물, 지방의 농도 정보를 이용하여 종양의 대사 및 혈관신 생 특성을 분석할 수 있다. 예를 들어 산화혈색소가 높은 경우 혈관신생으로 인해 혈액공급이 증가되었음을 의미하며, 탈산 화혈색소가 높은 경우는 종양의 성장으로 인한 대사 증가, 산 소 소비의 증가를 반영할 수 있다. 총 혈색소는 총 혈액량에
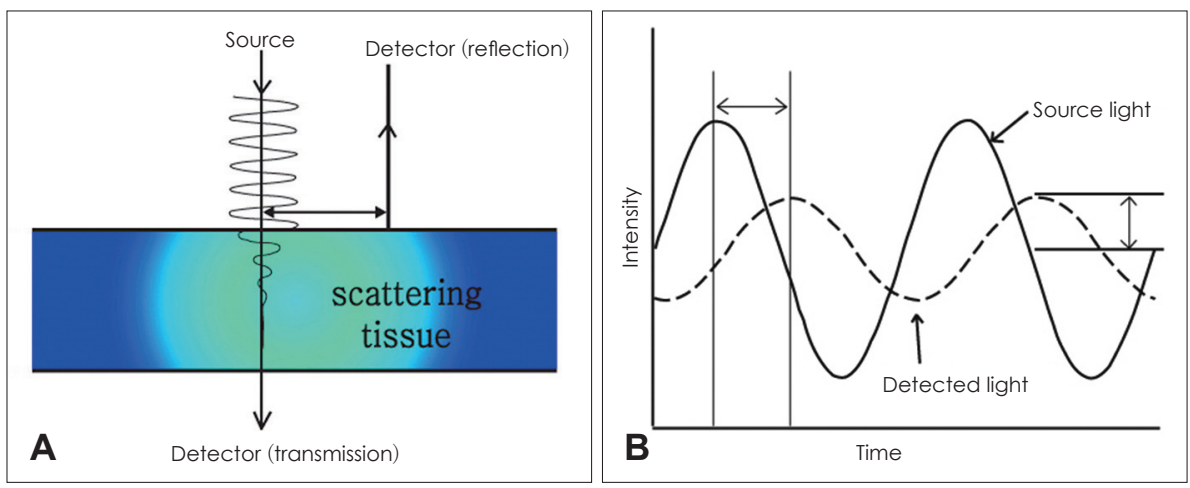

Fig. 1. Measurement of optical properties with frequency domain technique. Source light is transmitted or reflected $(A)$. Detected signal is diminished in amplitude (amplitude attenuation) and delayed in phase (phase shift) (B). 
해당하며 종양의 혈관밀도와 관련되어 있으며 산소포화도의 감소는 종양의 저산소증 또는 괴사의 지표가 될 수 있다. ${ }^{11-14)}$

주로 유방암에서 확산광분광영상을 이용한 분석이 많이 이루어졌는데 유방암 환자를 대상으로 확산광분광영상을 이용하여 기능적 광영상을 측정하였을 때 종양조직은 주변 정상 지방과 구별되는 대비를 보였을 뿐만 아니라, 항암화학 요법에 대하여 완전관해군과 불완전관해군 사이에 유의한 차 이를 보였다. ${ }^{9}$ 또한 이러한 차이는 항암화학요법 초기에 나타
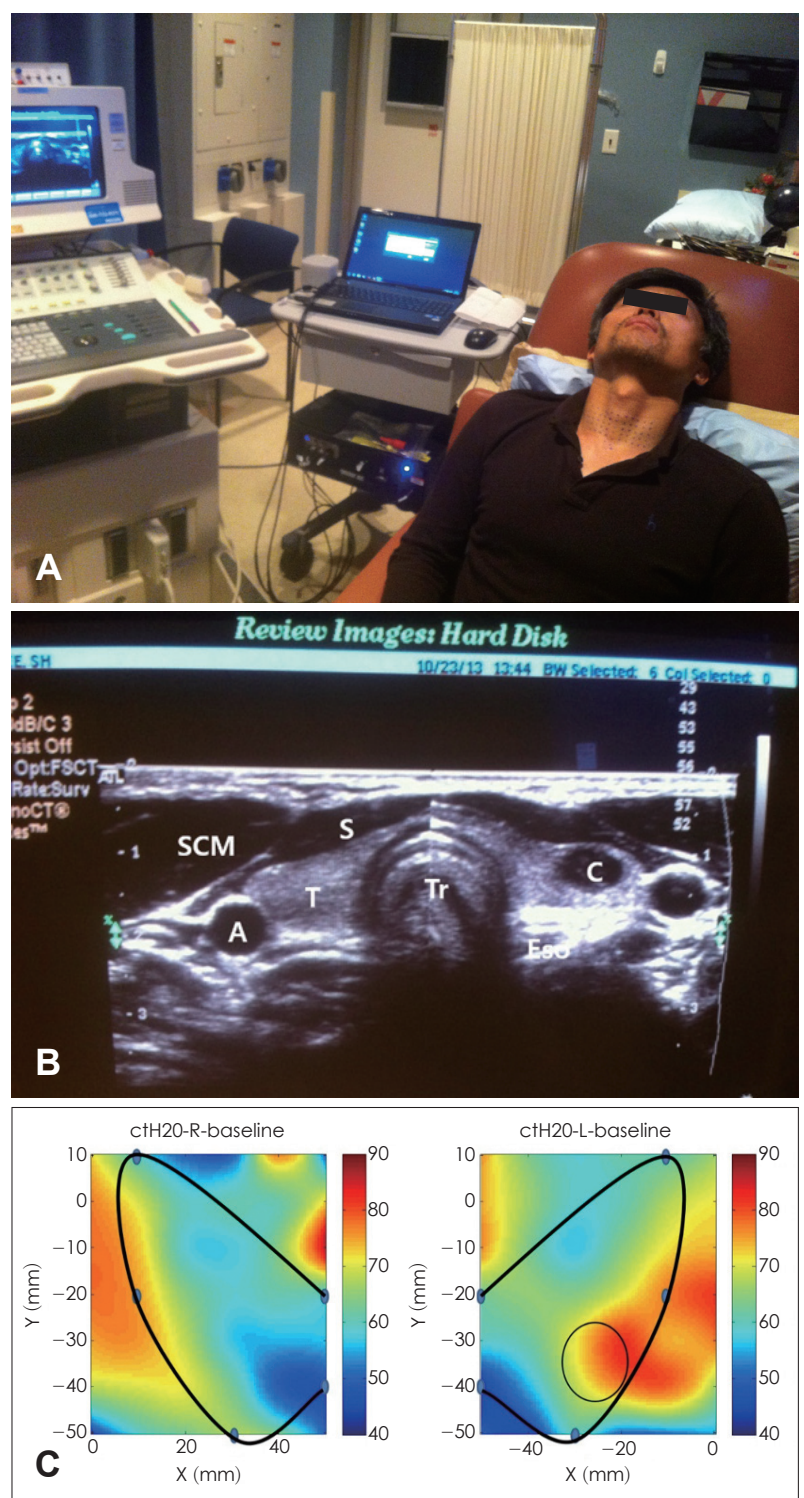

Fig. 2. Imaging of thyroid gland. DOSI system is found in the center of the photo during DOSI thyroid experiment. This miniaturized system provides faster measurement time at less cost and has equivalent accuracy (A). Ultrasound. Cystic nodule is found in left thyroid lobe on ultrasound (B). DOSI. Cyst is well visualized (black circle) on optical imaging for distribution of water concentration (C). Overall, both thyroid lobes have symmetry except for cyst location. DOSI: diffuse optical spectroscopic imaging, SCM: sternocleidomastoid muscle, S: strap muscle, A: carotid artery, T: thyroid gland, Tr: trachea, C: cyst.
났다. ${ }^{15)}$ 이러한 결과는 항암치료에 대한 반응 여부를 조기에 판단할 수 있어 항암치료를 계속할지, 아니면 구제수술을 시 행할지 결정하는 데 도움을 줄 수 있다. 두경부암의 경우에는 갑상선종양이나 경부림프절의 평가에 적용될 수 있다.

확산광분광영상은 측정 깊이가 $1.5 \sim 2 \mathrm{~cm}$ 정도로 경부를 신전하였을 때 경부 대부분이 측정 가능하다. 저자의 실험에 서는 갑상선을 초음파를 이용하여 계측한 후 확산광분광영 상을 이용하여 산화혈색소, 탈산화혈색소, 산소포화도, 물, 지 방의 분포에 대한 광영상을 측정하였다. 측정결과 정상갑상 선의 경우 갑상선 내부의 여러 위치 및 양측의 광학적 특성을 비교하였을 때 좌우의 광영상이 대칭적으로 보였으며 낭종의 경우 주변 조직과 대비되게 보였다(Fig. $2 \mathrm{~B}$ and C). 또한 갑상 선 내부의 광학적 변수들은 통계적으로 유의한 차이가 없이 일정한 범위의 수치를 보였다. 향후 정상 갑상선에서 확산광 분광영상의 각 변수들의 평균치를 얻는다면 비침습적으로 갑상선의 기능을 평가할 수도 있을 것이다. 이외에도 확산광 분광영상을 이용하여 전쟁터 같은 특수한 환경에서 외상 환 자의 비침습적이고 빠른 실혈 평가나 비만 환자에서 체지방의 분석에 연구가 진행되고 있다.

근적외선분광영상은 뇌의 혈액동태 감시(hemodynamic monitoring)에 많이 적용되고 있으며, positron emission tomography(PET)나 기능성 자기공명영상을 이용한 연구에서 이 명이 청각피질의 활동성과 관련이 있다라는 보고가 있다. ${ }^{2,16}$ Schecklmann 등 ${ }^{17)}$ 은 이명 환자에서 뇌피질을 근적외선분광 영상을 이용하여 측정하였고, 소리자극을 주었을 때 정상인에 비해 측두골 부위의 피질의 산소화 정도가 증가하였음을 보 고하였다. 이러한 결과는 근적외선분광영상이 이명의 병태생 리의 연구나 치료반응의 평가에 이용될 가능성을 보여준다.

\section{광간섭단층촬영(Optical Coherence Tomography, OCT)}

광간섭단층촬영은 빛의 간섭성(coherence)을 이용하여 생체 조직의 내부구조를 영상화하는 단층촬영(tomography) 기법 이다. ${ }^{18)}$ 여기서 간섭성이란 빛이 파동성을 가짐으로써 서로 보 강 및 상쇄되는 특성을 말한다.

광간섭단층촬영의 기전은 음파 대신 근적외선을 사용한다 는 점을 제외하면 초음파촬영과 유사하다. ${ }^{19)}$ 이해를 돕기 위 해 초음파의 원리를 간단히 설명하면, 초음파의 경우 보통 진 동수가 $15 \mathrm{MHz}$ 인 음파를 이용하며 해상도는 $0.15 \mathrm{~mm}$ 정도 이다. 이보다 높은 진동수를 사용하면 해상도가 증가하나 투 과 깊이는 감소된다. 생체조직에서 음파의 진행속도는 조직 의 경도(stiffness)와 밀도(density)에 따라 다르지만 연부조직 
에서는 보통 $1540 \mathrm{~m} / \mathrm{s}$ 정도이다. 초음파의 탐촉자(transducer) 에서 음파가 나와 조직의 경계 면에서 반사되어, 다시 탐촉자 로 돌아오는 시간을 측정하여 음파의 속도와 곱하면 조직의 깊이를 구할 수 있다. ${ }^{20)}$ 반사(reflection)는 음파가 서로 다른 조직의 경계 면에서 되돌아오는 성질을 말하며 예를 들어 낭 종 내부와 같이 균일한 조직이라면 초음파 반향(echo)을 형 성하지 못한다. 하지만 대부분의 생체 조직은 거시적이나 현 미경적으로 비균질성을 가지므로 특징적인 초음파 반향을 보인다. 일차원의 A-mode 영상의 경우 낭성 결절(cystic nodule)은 낭종의 앞벽과 뒷벽에서만 경계면의 특성이 확연히 달라 강한 반사, 즉 반향을 보이며 낭종의 중간 부위에서는 반 향이 나타나지 않게 된다. 반면에 고형 결절(solid nodule)은 결절의 내부에서도 다양하게 반사를 보이므로 결절 내부에 도 다양한 반향을 나타낸다. 탐촉자가 조직을 지나갈 때 측정 된 일련의 A-mode 영상을 배열함으로써 이차원적인 B-mode 영상을 얻게 된다.

광간섭단층촬영의 경우에도 초음파촬영과 비슷하게 반사 된 광원을 측정하여 영상을 얻는다. 광원에서 나온 빛이 광분 할기(beam splitter)를 통해 한쪽으로는 기준 거울(reference mirror)로 입사되고, 다른 쪽으로는 조직으로 입사된다. 생체 조직에 입사된 빛은 조직내부의 모든 깊이의 층에서 반사된 다. 조직에서 반사된 빛과 기준거울에서 반사된 빛이 간섭계 에서 다시 만나게 되고, 두 빛의 경로차에 따라 빛이 보강 또는 상쇄 간섭을 일으키게 되며 이를 광검출기에서 검출한다. 이때 기준거울을 이동시켜 조직내부의 미세구조에 의해 반사되는 빛에 의한 간섭무늬를 깊이별로 얻어낼 수 있으며(A-mode scanning), 입사광을 횡방향(lateral scanning)으로 이동시켜 같은 과정을 반복함으로써 이차원 단면이미지(B-mode scanning) 를 구현할 수 있다. ${ }^{21}$

광간섭단층촬영은 초음파, $\mathrm{CT}, \mathrm{MRI}$ 등 다른 영상장비에 비 해 투과 깊이가 $2 \mathrm{~mm}$ 정도로 얕은 한계를 가지고 있지만 해 상도가 뛰어나다. 광간섭단층촬영의 분해능은 $10 \mu \mathrm{m}$ 로 초음 파에 비해 15 배 이상 훨씬 우수한 성능을 가지고 있다. ${ }^{22,23)}$ 특 히 기준거울을 이동시켜야 하므로 스캔속도가 제한되는 시간 영역(time-domain) 광간섭단층촬영 대신, 주파수영역(frequency-domain or Fourier-domain) 광간섭단층촬영이 개 발되어 영상획득 속도가 높으며 더 선명한 영상을 얻을 수 있 게 되었다. 또한 광원에 있어서도 $1310 \mathrm{~nm}$ 의 초발광 다이오드 (superluminescent diode)가 일반적으로 사용되지만 고속 주 파수 변이 레이저(frequency-sweeping laser)를 사용함으로써 초음파와 같은 실시간 영상 획득이 가능해졌다. ${ }^{24}$

\section{광간섭단층촬영의 임상적 적용}

광간섭단층촬영이 가장 먼저 적용된 임상 분야는 안과에서 의 망막 및 각막진단 분야이며 이미 상품화되어 널리 사용되 고 있는 실정이다. 이외에도 심혈관계 질환에 내시경용 광간 섭단층촬영도 개발되어 있다. 두경부 영역에서는 후두 점막 질환, 기도협착, 갑상선수술 등에서 다양한 연구가 이루어지 고 있다.

\section{후두점막병변}

후두에는 여러 종류의 양성 및 악성 점막 병변이 발생한다. 후두내시경을 통한 육안적 관찰을 통해 대부분 구별이 가능 하지만 광간섭단층촬영은 성대의 단면을 관찰할 수 있는 장점 이 있다. 또한 광간섭단층촬영 장치의 광섬유의 두께가 $1 \mathrm{~mm}$ 정도로 굴곡형 내시경에 부착하여 광간섭단층촬영 영상을 내 시경 영상과 동시에 얻을 수 있다. ${ }^{25}$

정상 성대에서 상피층(epithelium)은 비교적 균일하게 상피 세포로 이루어져 있어 빛을 적게 산란시키므로 광간섭단층 촬영에서 낮은 신호강도를 보인다. 이에 반해 고유층은 아교 섬유(collagen fiber), 탄력섬유(elastic fiber), 혈관, 림프관 등 으로 구성되어 높은 신호강도를 보인다. 상피층과 고유층은 신 호강도의 차이로 인하여 잘 구별되며 경계부가 기저막(basement membrane)이 된다. $2 \mathrm{~mm}$ 이상의 깊이에서는 신호강도 가 감소되어 해부학적 구조가 잘 관찰되지 않는다. 성문하부 에서는 고유층에서 군데군데 저신호강도의 분비선이 위치하 며, 고유층 아래에 저신호 강도의 연골이 관찰된다. ${ }^{26}$

라인케 부종에서는 고유층에 저신호강도를 보이는 경계가 좋은 액체저류(fluid collection)가 많이 관찰된다. 성대낭종 에서는 낭종 및 낭종벽의 표면상피를 관찰할 수 있다. 용종은 정상 혹은 약간 상피층이 두꺼워져 있으며 고유층이 정상보다 약간 저신호강도를 보인다. 과각화증이나 이형성증은 특징적 으로 상피층이 두꺼워져 있으며 기저막은 잘 관찰된다. 후두유 두종도 상피층이 두꺼워져 있으며 섬유혈관핵(fibrovascular core)이 보이기도 한다. 기저막은 잘 유지되어 있지만 외장성 (exophytic) 유두종의 경우 투과 깊이의 한계 때문에 관찰이 되지 않는 경우도 있다. ${ }^{19,26)}$ 후두암과 양성 및 전암성 병변을 구분하는 가장 중요한 광간섭단층촬영 소견은 기저막이 잘 유 지되는지 여부이다. 병변이 작은 경우에는 광간섭단층촬영으 로 기저막의 침윤여부가 잘 확인이 되지만 종괴가 크고 외장 성인 경우에는 기저막의 상태를 확인하기 어려운 한계가 있다. 또한 후두암에서는 상피층에 혈관이 관찰되기도 한다. ${ }^{27)}$

\section{기도 협착}

신생아 중환자실에서 삽관(intubation)된 유아의 약 0.2 3.0\% 
정도에서 후천적인 성문하협착증(subglottic stenosis)이 발생 하는 것으로 알려져 있으며 $0.005 \%$ 에서는 수술적 치료가 필
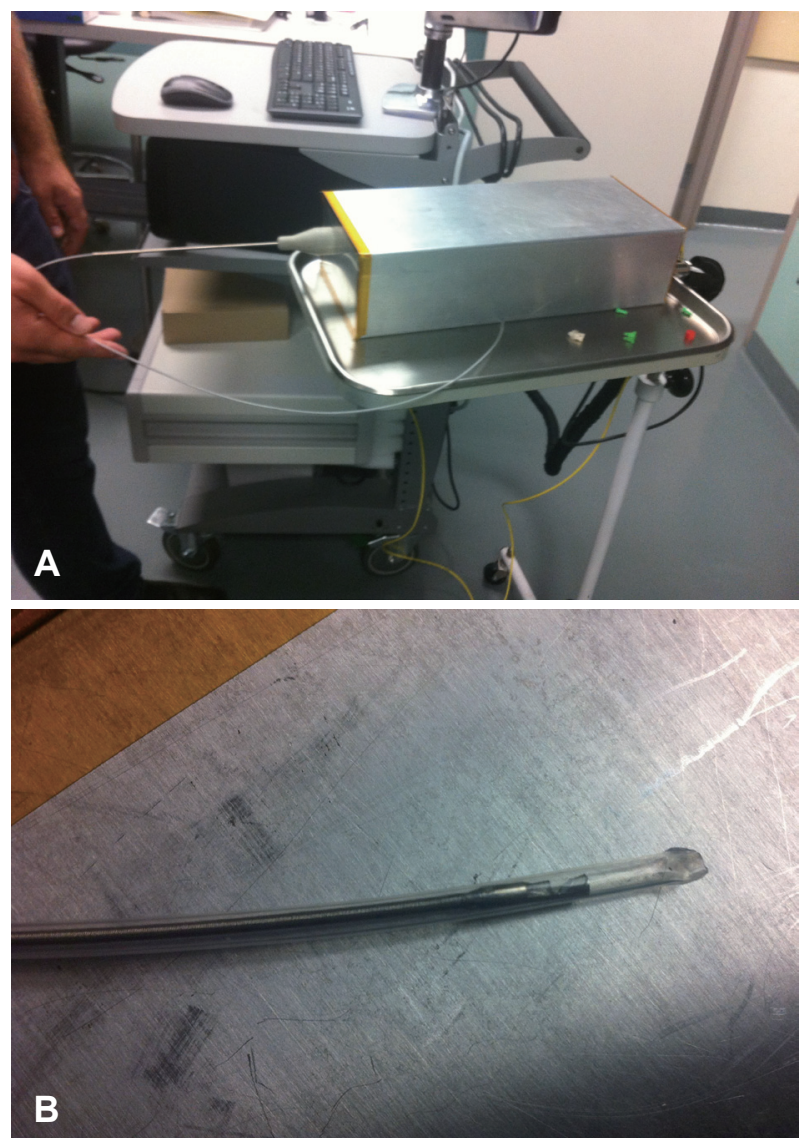

Fig. 3. Swept source FD-OCT. OCT system. Rotational scanning with constant velocity ( 25 frames per second) is accomplished by the motor. During imaging, the probe is proximally rotated within the plastic sheath (A). OCT probe inside the plastic sheath. Diameters of the probe and fiber are $1.2 \mathrm{~mm}$ and $0.96 \mathrm{~mm}$ (B). FD-OCT: Fourier domain optical coherence tomography.
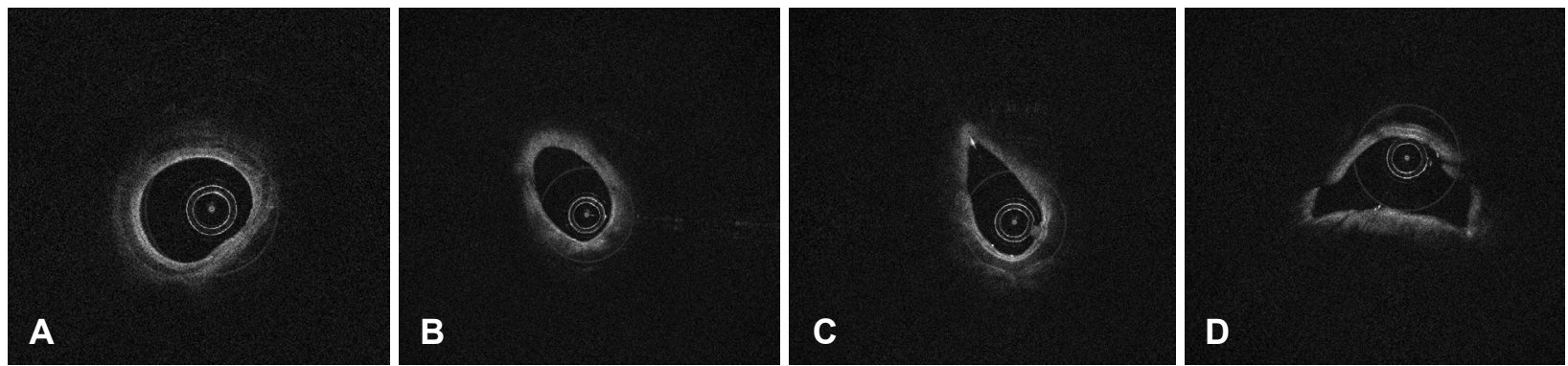

Fig. 4. Rabbit airway measured by OCT. Trachea (A), subglottis (B), glottis (C), epiglottis (D). OCT: optical coherence tomography.

Fig. 5. Linear OCT images of the subglottis. Thickness of lamina propria was significantly increased. Day 0 (A), day 7 (B), day 14 (C). OCT: optical coherence tomography.
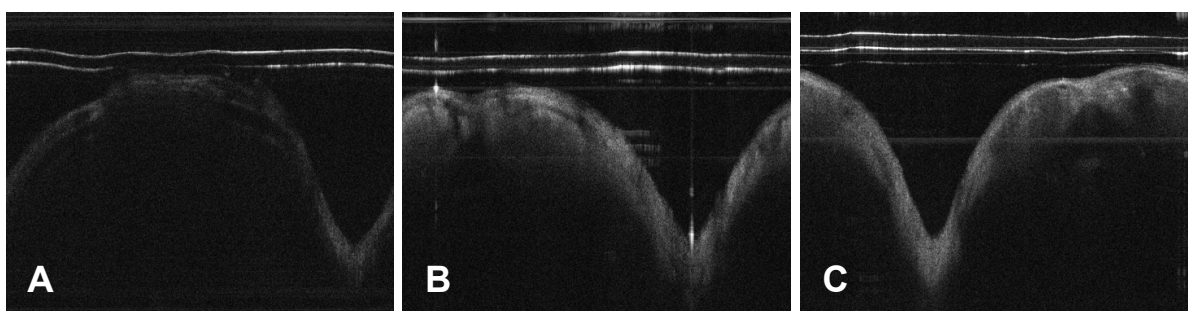


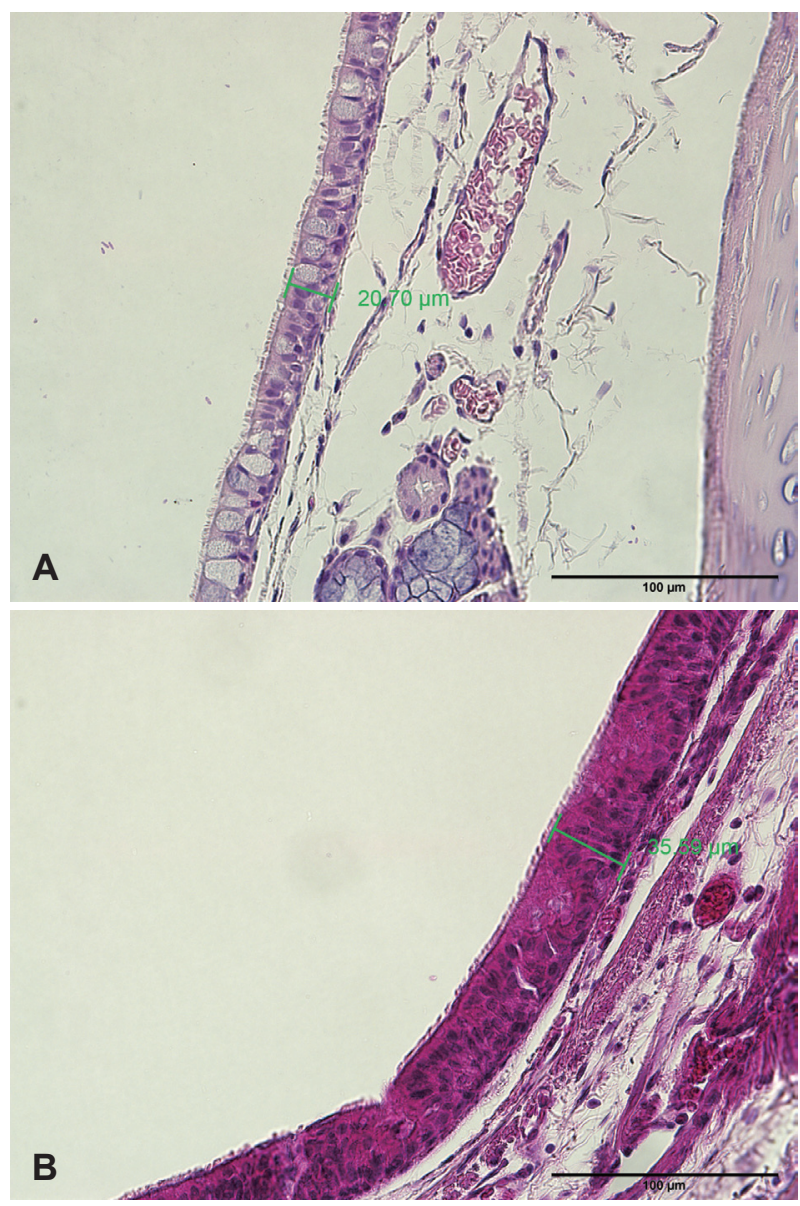

Fig. 6. Pathologic specimen of the subglottis. Thickness of epithelial layer was significantly increased. Non-intubation group (A), intubation group (B). H\&E $(\times 400)$.

직(granulation tissue)의 형성을 용이하게 검사할 수 있다. ${ }^{22,24)}$ 또한 임상에서 신생아의 삽관튜브내로 삽입하여 조기에 기도 점막의 미세구조의 변화를 측정하는 데에도 사용될 수 있다.23)

\section{갑상선수술}

갑상선수술의 가장 흔하고 중요한 합병증은 저칼슘혈증이 다. 부갑상선을 보존하기 위하여 수술시 조심스럽게 박리를 하지만, 주변 조직과 구별하기 어려운 경우가 많아 부갑상선 을 확인하는 가장 확실한 방법은 동결절편(frozen section) 검사이다. 하지만 동결절편 검사는 수술 시간을 증가시키며, 조직을 환자로부터 떼어내야만 하는 문제점이 있다. 광간섭 단층촬영은 해상도가 높으며 조직을 고정하거나 염색할 필요 없이, 조직검사 수준의 영상을 얻을 수 있다. 따라서 광간섭단 층촬영을 이용하면 비침습적으로 부갑상선을 지방조직, 림 프절, 갑상선, 근육과 구별하는 데 도움이 된다. ${ }^{34-36)}$

\section{결 론}

광영상 기술은 빛을 사용하므로 인체에 무해하고 비침습적 인 특성을 가지고 있다. 확산광분광영상을 포함한 기능적 근 적외선분광영상은 아직 임상에서 사용되고 있지는 않지만 뇌 기능에 관한 많은 연구가 이루어지고 있으며 이비인후과 영 역에서는 갑상선이나 경부 종양의 진단, 이명 등에 이용될 수 있을 것이다. 광간섭단층촬영은 안과 영역에서는 확고하게 시 장성을 확보하였고, 뛰어난 해상도와 실시간 영상획득 능력으 로 상기도 및 하기도 질환, 갑상선 등 이비인후과 영역에서 활 용 가능성이 높을 것으로 기대된다.

\section{REFERENCES}

1) Ferrari M, Quaresima V. A brief review on the history of human functional near-infrared spectroscopy (fNIRS) development and fields of application. Neuroimage 2012;63(2):921-35.

2) Lloyd-Fox S, Blasi A, Elwell CE. Illuminating the developing brain: the past, present and future of functional near infrared spectroscopy. Neurosci Biobehav Rev 2010;34(3):269-84.

3) O’Sullivan TD, Cerussi AE, Cuccia DJ, Tromberg BJ. Diffuse optical imaging using spatially and temporally modulated light. J Biomed Opt 2012;17(7):071311.

4) Elwell CE, Cooper CE. Making light work: illuminating the future of biomedical optics. Philos Trans A Math Phys Eng Sci 2011;369 (1955):4358-79.

5) Patterson MS, Chance B, Wilson BC. Time resolved reflectance and transmittance for the non-invasive measurement of tissue optical properties. Appl Opt 1989;28(12):2331-6.

6) Bonner RF, Nossal R, Havlin S, Weiss GH. Model for photon migration in turbid biological media. J Opt Soc Am A 1987;4(3):423-32.

7) Chance B, Leigh JS, Miyake H, Smith DS, Nioka S, Greenfeld R, et al. Comparison of time-resolved and -unresolved measurements of deoxyhemoglobin in brain. Proc Natl Acad Sci U S A 1988;85(14): 4971-5.

8) Bevilacqua F, Berger AJ, Cerussi AE, Jakubowski D, Tromberg BJ. Broadband absorption spectroscopy in turbid media by combined frequency-domain and steady-state methods. Appl Opt 2000;39(34): 6498-507.

9) Ueda S, Roblyer D, Cerussi A, Durkin A, Leproux A, Santoro Y, et al. Baseline tumor oxygen saturation correlates with a pathologic complete response in breast cancer patients undergoing neoadjuvant chemotherapy. Cancer Res 2012;72(17):4318-28.

10) No KS, Kwong R, Chou PH, Cerussi A. Design and testing of a miniature broadband frequency domain photon migration instrument. J Biomed Opt 2008;13(5):050509.

11) Pakalniskis MG, Wells WA, Schwab MC, Froehlich HM, Jiang S, Li $\mathrm{Z}$, et al. Tumor angiogenesis change estimated by using diffuse optical spectroscopic tomography: demonstrated correlation in women undergoing neoadjuvant chemotherapy for invasive breast cancer? Radiology 2011;259(2):365-74.

12) Denko NC. Hypoxia, HIF1 and glucose metabolism in the solid tumour. Nat Rev Cancer 2008;8(9):705-13.

13) Vaupel P, Schlenger K, Knoop C, Höckel M. Oxygenation of human tumors: evaluation of tissue oxygen distribution in breast cancers by computerized O2 tension measurements. Cancer Res 1991;51(12): 3316-22.

14) Okunieff P, Hoeckel M, Dunphy EP, Schlenger K, Knoop C, Vaupel P. Oxygen tension distributions are sufficient to explain the local 
response of human breast tumors treated with radiation alone. Int J Radiat Oncol Biol Phys 1993;26(4):631-6.

15) Jiang S, Pogue BW, Kaufman PA, Gui J, Jermyn M, Frazee TE, et al. Predicting breast tumor response to neoadjuvant chemotherapy with diffuse optical spectroscopic tomography prior to treatment. Clin Cancer Res 2014;20(23):6006-15.

16) Lanting $C P$, de Kleine $E$, van Dijk P. Neural activity underlying tinnitus generation: results from PET and fMRI. Hear Res 2009;255(1-2):1-13.

17) Schecklmann M, Giani A, Tupak S, Langguth B, Raab V, Polak T, et al. Functional near-infrared spectroscopy to probe state- and trait-like conditions in chronic tinnitus: a proof-of-principle study. Neural Plast 2014;2014:894203.

18) Kraft M, Lüerssen K, Lubatschowski H, Glanz H, Arens C. Technique of optical coherence tomography of the larynx during microlaryngoscopy. Laryngoscope 2007;117(5):950-2.

19) Kraft M, Glanz H, von Gerlach $S$, Wisweh $H$, Lubatschowski $H$, Arens C. Clinical value of optical coherence tomography in laryngology. Head Neck 2008;30(12):1628-35.

20) Levine RA. Thyroid ultrasound physics. In: Baskin HJ, Duick DS, Levine RA, editors. Thyroid Ultrasound and Ultrasound-Guided FNA. 3rd ed. New York: Springer;2013. p.9-28.

21) Huang D, Swanson EA, Lin CP, Schuman JS, Stinson WG, Chang W, et al. Optical coherence tomography. Science 1991;254(5035): 1178-81.

22) Lin JL, Yau AY, Boyd J, Hamamoto A, Su E, Tracy L, et al. Real-time subglottic stenosis imaging using optical coherence tomography in the rabbit. JAMA Otolaryngol Head Neck Surg 2013;139(5):502-9.

23) Volgger V, Sharma GK, Jing JC, Peaks YS, Loy AC, Lazarow F, et al. Long-range Fourier domain optical coherence tomography of the pediatric subglottis. Int J Pediatr Otorhinolaryngol 2015;79(2): $119-26$.

24) Jing J, Zhang J, Loy AC, Wong BJ, Chen Z. High-speed upper-airway imaging using full-range optical coherence tomography. J Biomed Opt 2012;17(11):110507.

25) Sepehr A, Armstrong WB, Guo S, Su J, Perez J, Chen Z, et al. Optical coherence tomography of the larynx in the awake patient. Otolaryngol Head Neck Surg 2008;138(4):425-9.

26) Wong BJ, Jackson RP, Guo S, Ridgway JM, Mahmood U, Su J, et al.
In vivo optical coherence tomography of the human larynx: normative and benign pathology in 82 patients. Laryngoscope 2005;115(11): 1904-11.

27) Armstrong WB, Ridgway JM, Vokes DE, Guo S, Perez J, Jackson $\mathrm{RP}$, et al. Optical coherence tomography of laryngeal cancer. Laryngoscope 2006;116(7):1107-13.

28) Leung R, Berkowitz RG. Incidence of severe acquired subglottic stenosis in newborns. Int J Pediatr Otorhinolaryngol 2007;71(5): 763-8.

29) Walner DL, Loewen MS, Kimura RE. Neonatal subglottic stenosis-incidence and trends. Laryngoscope 2001;111(1):48-51.

30) Roh JL, Lee YW, Park HT. Subglottic wound healing in a new rabbit model of acquired subglottic stenosis. Ann Otol Rhinol Laryngol 2006;115(8):611-6.

31) Hanauer AD, Fraga JC, Sousa JK, Sanches PR, Duarte ME, UlbrichKulczynski J, et al. Electrocautery versus $23 \% \mathrm{NaOH}$ infiltration to induce subglottic stenosis in a canine experimental model. Pediatr Surg Int 2007;23(12):1227-31.

32) Chafin JB, Sandulache VC, Dunklebarger JL, Otteson TD, Hoffmann PJ, Hebda PA, et al. Graded carbon dioxide laser-induced subglottic injury in the rabbit model. Arch Otolaryngol Head Neck Surg 2007; 133(4):358-64.

33) Kelly NA, Murphy M, Giles S, Russell JD. Subglottic injury: a clinically relevant animal model. Laryngoscope 2012;122(11):257481.

34) Conti de Freitas LC, Phelan E, Liu L, Gardecki J, Namati E, Warger WC, et al. Optical coherence tomography imaging during thyroid and parathyroid surgery: a novel system of tissue identification and differentiation to obviate tissue resection and frozen section. Head Neck 2014;36(9):1329-34.

35) Ladurner R, Hallfeldt KK, Al Arabi N, Stepp H, Mueller S, Gallwas JK. Optical coherence tomography as a method to identify parathyroid glands. Lasers Surg Med 2013;45(10):654-9.

36) Sommerey S, Al Arabi N, Ladurner R, Chiapponi C, Stepp H, Hallfeldt $\mathrm{KK}$, et al. Intraoperative optical coherence tomography imaging to identify parathyroid glands. Surg Endosc 2014 Dec 5 [Epub]. http:// dx.doi.org/10.1007/s00464-014-3992-x.

\section{정답 및 해설}

답 (5)

해 설 후두결핵.

후두결핵은 항결핵제를 9 12개월 동안 투여하며 성대안정이 필요하다. 약물치료에 반응하지 않는 경우 조직검사를 통한 확진이 필요하다. Reference: 이비인후과학 두경부외과학 (대한이비인후과학회편, 일조각). p.1684 5. 